\title{
USE AND RESPONSE TO PHOSPHORUS BY POTATO CLONES IN TWO CROPPING SYSTEMS
}

\author{
UTILIZAÇÃO E RESPOSTA AO FÓSFORO POR CLONES DE BATATA EM DOIS \\ SISTEMAS DE CULTIVO
}

\author{
Darlene SAUSEN $^{1 *}$; Ivan Ricardo CARVALHO ${ }^{2}$; Júlia Gomes FARIAS ${ }^{3}$; \\ Athos Odin Severo DORNELES ${ }^{4}$; Aline Soares PEREIRA ${ }^{4}$; Ritieli Baptista MAMBRIN ${ }^{5}$; \\ Francine LAUTENCHLEGER ${ }^{6}$; Fernando Teixeira NICOLOSO${ }^{1}$ \\ 1. Federal University of Santa Maria, Santa Maria, RS, Brazil *darlene_sn@yahoo.com.br; 2. Northwest Regional University of the \\ State of Rio Grande do Sul, Ijuí, RS, Brazil; 3. Benedictine University, Mesa, Arizona, USA; 4. Federal University of Pelotas, Pelotas, \\ RS, Brazil; 5. Riograndense Higher Education Center, Marau, RS, Brazil \\ 6. University of the Midwest, Guarapuava, PR, Brazil
}

\begin{abstract}
The selection of potato plants (Solanum tuberosum L.) that are efficient in the use of phosphorus $(\mathrm{P})$ plays an important role in increasing crop productivity, reducing the cost of production due to the high price of phosphate fertilizers, as well as reducing the pollution of the environment due to the better use of the applied fertilizers. The objective of this work was to compare the method of selection of potato clones for the efficiency of use and response to P between in vitro and off - soil systems with the use of sand as substrate. To that end, potato clones SMIC 148-A, Dakota Rose, SMINIA 793101-3, SMIB 106-7, SMIF 212-3, SMIJ $319-1$ and $\mathrm{P} 150$ were cultivated at low and high levels of $\mathrm{P}$ in the culture systems in vitro $(1,935$ and 19,346 $\left.\mathrm{mg} \mathrm{P} \mathrm{L}{ }^{-1}\right)$ and off-soil $\left(2.32\right.$ and $\left.23.2 \mathrm{mg} \mathrm{P} \mathrm{L}^{-1}\right)$. The selection of potato clones using only as a criterion the accumulation of $\mathrm{P}$ under low nutrient level is not adequate, both in off-soil and in vitro cultivation. Clones selected as being more efficient in the use of $\mathrm{P}$ in in vitro cultivation do not prove to be necessarily more efficient in off-soil cultivation. No clone remains in the same classification group regarding the efficiency of use and response to $\mathrm{P}$, based on the production of dry mass, in the two cropping systems.
\end{abstract}

KEYWORDS: In vitro culture. Mineral nutrition. Off-soil cultivation. Selection of clones. Solanum tuberosum L.

\section{INTRODUCTION}

To ensure food production for the growing population projected for 2050 by 9.8 billion people (UN, 2017) improvements are needed in agricultural productivity and in the use of natural resources (GODFRAY et al., 2010; TESTER; LANGRIDGE, 2010). Phosphorus (P) is one of these resources that are extremely necessary for the production of food throughout the planet (FARIAS et al., 2017; WISSUWA et al., 2015).

The potato (Solanum tuberosum L.) is one of the most consumed foods in the world and is among the main agricultural commodities produced in Brazil (FERNANDES et al., 2016). The ideal growth of potato plants and high yields of tubers depends on the availability of $\mathrm{P}$ in the soil and on the ability of the plant to absorb and utilize this element (FERNANDES; SORATTO, 2012; ROSEN; BIERMAN, 2008). The selection of potato plants that are efficient in the use of phosphorus (P) plays an important role in increasing crop productivity, reducing the cost of production due to the high price of phosphate fertilizers, as well as the reduction of environmental pollution in the best use of the applied fertilizers.

Plants considered efficient in the use of $\mathrm{P}$ are those that produce the highest amount of biomass associated with the lowest nutrient consumption, either in low availability or in adequate supply of P (MOURA et al., 2001; WISSUWA et al., 2015), which allows differentiated fertilization regime between cultivars (ROSE; WISSUWA, 2012; HEUER et al., 2017). Since both deficient and well-supplied plants in $P$ can present high efficiency indices, it is necessary to select those plants that, besides being efficient in the use of P, have high yields (HAMMOND et al., 2008; SIDDIQI; GLASS, 1981; WISSUWA, et al., 2015). For the identification of efficient cultivars in the acquisition and utilization of a nutrient it is essential to establish fast and inexpensive methods. These methods should provide the distinction of germplasm, with high repeatability of the results, and should also allow the evaluation of a large number of plants or populations at the same time and if possible, still in the seedling stage (SILVA et al., 2004). SILVA; PEREIRA, 2011). 
In this sense, in vitro and off-soil cultivation methods have allowed, in recent years, an increase in the production of potato mini-tubers with important repercussions in reducing the production cycle of seed tubers, increasing seed quality and reducing the incidence of diseases (MILLAM, SHARMA, 2008). In addition, these production systems also allow a better control of the mineral nutrition of the plants (BISOGNIN et al., 2015), which facilitates the execution of experiments to select clones that are efficient in the absorption and utilization of nutrients and realization of an early selection, reducing expenditures on labor, consumption materials and area for production (SILVA; PEREIRA, 2011). Thus, the objective of the present work was to compare the in vitro and off-soil systems with the use of sand as substrate in the selection of potato clones for the efficiency of use and response to $P$.

\section{MATERIAL AND METHODS}

For the in vitro experiment, the plant material used consisted of seven potato clones from the Potato Genetics and Breeding Program of the Federal University of Santa Maria: SMIC 148-A, Dakota Rose, SMINIA 793101-3, SMIB 106-7, SMIF 212-3, SMIJ 319-1 and P 150. Multiplication of these clones was performed by stalk explants obtained from plants grown in vitro in standard MS culture medium (MURASHIGE; SKOOG, 1962). The $1.0 \mathrm{~cm}$ long nodal segments were inoculated in MS medium supplemented with $30 \mathrm{~g} \mathrm{~L}^{-1}$ sucrose, $0.1 \mathrm{~g} \mathrm{~L}^{-1}$ myo-inositol and $6 \mathrm{~g} \mathrm{~L}^{-1}$ agar. Phosphorus treatments consisted of 5 and $50 \%$ of the standard $\mathrm{P}$ concentration of the MS medium, referred to in this work as low $\left(1,935 \mathrm{mg} \mathrm{P} \mathrm{L}^{-1}\right)$ and high $(19,346 \mathrm{mg}$ $\mathrm{P} \mathrm{L}^{-1}$ ) P levels. $\mathrm{P}$ source was $\mathrm{KH}_{2} \mathrm{PO}_{4}$. To maintain the potassium content, the $\mathrm{KCl}$ was used. Thus, the contents of the other nutrients were kept the same for both treatments.

The experimental unit consisted of ten test tubes, each containing $10 \mathrm{~mL}$ of culture medium and three nodal segments with one gem and leaf, and four replicates were used in a completely randomized design. The test tubes containing the explants were kept in a growth room with a temperature of $25 \pm 2{ }^{\circ} \mathrm{C}$ and a photoperiod of $16 \mathrm{~h}$ with luminous intensity of $35 \mu \mathrm{mol} \mathrm{m} \mathrm{m}^{-2} \mathrm{~s}^{-1}$ supplied by cold white fluorescent lamps. The plants were collected at 40 days after inoculation (DAI). The shoot, root and total dry mass were determined after drying of the material for 15 days in oven at $65^{\circ} \mathrm{C}$.

For the off-soil experiment, conducted in a greenhouse, in the city of Santa Maria - RS, Brazil
( $29^{\circ} 42^{\prime} 56^{\prime \prime} \mathrm{S}, 53^{\circ} 43^{\prime} 13^{\prime \prime} \mathrm{W}$ and elevation of $95 \mathrm{~m}$ ), the same clones of the in in vitro experiment were used. The plants used were from potato plants micropropagated and acclimatized for 14 days in a soil cultivation system, kept under shade cloth $(60 \%$ light extinction) for 5 days. Subsequently, transplanting was performed for a culture system composed of a black polyethylene tray with sand as substrate (BANDINELLI et al., 2013). Three irrigations were carried out, with nutrient solution during the day, with the duration of $15 \mathrm{~min}$ each, with the aid of a digital programmer and a pump of low flow so that all the substrate was saturated of solution. The excess solution was drained through a hole in the base of the tray returning to the nutrient solution reservoir. Each tray contained twelve plants in a 10 by $10 \mathrm{~cm}$ spacing.

The $\mathrm{P}$ treatments consisted of 5 and $50 \%$ of the standard concentration of $\mathrm{P}$ in the nutrient solution for the off-soil cultivation of potato described by Bisognin et al. (2015), which are referred to in this work as Low $\left(2.32 \mathrm{mg} \mathrm{P} \mathrm{L}^{-1}\right)$ and high (23.2 $\mathrm{mg} \mathrm{P} \mathrm{L}^{-1}$ ) of $\mathrm{P}$ levels. To maintain the potassium content of the nutrient solution, $\mathrm{KCl}$ was used. The electrical conductivity (EC) was maintained at $2 \mathrm{dS} \mathrm{m}^{-1}$ (water was used to reduce $\mathrm{EC}$ when necessary) and $\mathrm{pH}$ at 5.7 adjusted every two days by the addition of $\mathrm{HCl}$. The experiment was conducted in a $7 \times 2$ factorial (seven clones and two $\mathrm{P}$ levels) in a randomized block design using six replicates. The experimental unit consisted of three plants. At 62 days after planting (DAP) some clones showed visible signs of senescence beginning when cultivated at the low P level, and the experiment was finished. The dry mass of leaves, stems, tubers and roots was determined after drying for 15 days in a greenhouse at $65^{\circ} \mathrm{C}$.

The determination of the $\mathrm{P}$ concentration in the tissues was carried out in the Industrial and Environmental Chemistry laboratory of the Federal University of Santa Maria. Samples of the dry mass of the plants of the two cropping systems were ground and submitted to an acid digestion procedure in an open system with a digester block (Velp Scientifica, Model DK, Italy). Samples were preweighed and transferred to the decomposition vials. To each sample was added $5 \mathrm{~mL}$ of $\mathrm{HNO}_{3} 14$ mol L ${ }^{-1}$. The tubes were capped and held at $140^{\circ} \mathrm{C}$ for $2 \mathrm{~h}$. After the digestion step, the samples were transferred to polypropylene vials and added to 25 $\mathrm{mL}$. The determination of $\mathrm{P}$ was performed by inductively coupled plasma optical emission spectrometry (ICP-OES) on a Perkin Elmer spectrometer (Optima 4300 DV, USA) equipped with Gencone ${ }^{\circledR}$ nebulizer, cyclone type nebulizer 
chamber and quartz torch with injector of alumina of $2.0 \mathrm{~mm}$ internal diameter. The amount of $\mathrm{P}$ accumulated in the leaves, roots, stems and tubers was obtained by multiplying the $\mathrm{P}$ concentration and the dry mass of the plant tissue. Based on the proposal of Siddiqi and Glass (1981) the efficiency indexes of P (EIP) were determined in the roots and shoots of the plants cultivated in vitro and, in the roots and leaves of the plants cultivated off-soil by the equation: $\mathrm{EIP}=(\mathrm{mg} \text { tissue dry mass })^{2}$. $(\mu \mathrm{g}$ of $\mathrm{P}$ accumulated in the tissue) ${ }^{-1}$.

Statistical analysis of the data of the two experiments was performed using the software Sisvar 5.3 (FERREIRA, 2011). The means between clones and the effect of P levels were compared by the Scott-Knott 5\% test (SCOTT; KNOTT, 1974).

In order to classify the clones as to the efficiency of use and response to $\mathrm{P}$ for the production of shoot and root dry mass of the in vitro culture and for the production of dry mass of leaves and roots of the crop off-soil, diagrams according to Fox (1978) were performed. For the graphical representation in the Cartesian plane we have in the $\mathrm{x}$ axis the dry mass of the tissue verified under a low level of $\mathrm{P}$ and in the axis $\mathrm{y}$, a response to the application of $\mathrm{P}$, where the difference between the dry mass production in the two levels of $\mathrm{P}$ was divided by the difference in levels of $\mathrm{P}$ applied. The origin of the horizontal axis was the average dry mass production at the low $\mathrm{P}$ level of all clones, while the vertical axis origin point was the mean of the applied $\mathrm{P}$ response of all clones. The diagrams were divided into four quadrants that separate the clones into groups. In the first quadrant the efficient and responsive clones are represented; in the second, the efficient and non-responsive; in the third the non efficient and non responsive; and in the fourth the not efficient and responsive.

\section{RESULTS AND DISCUSSION}

In the in vitro cultivation, the $\mathrm{P}$ accumulation and the $P$ efficiency use (EIP) in the roots were influenced only by the factors alone and in the cultivation off-soil, the same occurred for the EIP in the leaves (Table 1). P accumulation in the roots in in vitro cultivation was $71 \%$ lower than that observed at high $\mathrm{P}$ levels and in the shoot, $\mathrm{P}$ accumulation was also higher at the high $\mathrm{P}$ level for all clones, showing that the higher the $\mathrm{P}$, the greater is the biomass production, as well as the increase of $\mathrm{P}$ accumulation in tissues (SORATTO et al., 2015).

The SMINIA 793101-3 and P 150 clones accumulated less $\mathrm{P}$ in the roots than the other clones, and in the shoot, under high $\mathrm{P}$ level in the culture medium, clone SMIC 148-A was the one that accumulated more $\mathrm{P}\left(31.4 \mu \mathrm{gP} \mathrm{pl}^{-1}\right)$ and Dakota Rose, the less $\left(13.3 \mu \mathrm{gP} \mathrm{pl}^{-1}\right)$, whereas in the low $\mathrm{P}$ level it was not possible to differentiate the potato clones by the accumulation $\mathrm{P}$ in the shoot (Table 1). The difficulty of differentiating potato clones cultivated at a low level of this nutrient in relation to $\mathrm{P}$ accumulation has also been reported by Balemi (2011), where the author suggests that the accumulation of $\mathrm{P}$ in the shoot under low nutrient supply is not a good parameter to classify potato clones when they differ in efficiency of use. The lower accumulation of $\mathrm{P}$ by plants cultivated at low $\mathrm{P}$ levels was a direct response to the lower supply of this nutrient, which shows that only this characteristic can not be used to differentiate the clones.

In the off-soil cultivation, $\mathrm{P}$ accumulation in the roots was $87,80,79$ and $55 \%$ lower at the low level than that observed at high $\mathrm{P}$ levels for the SMIC 148-A, Dakota Rose, SMINIA 793101-3 and $\mathrm{P}$ 150, respectively. The SMIJ 319-1 clone accumulated the highest $\mathrm{P}$ in the roots in low (8229 $\left.\mu g P . p^{-1}\right)$ and high (6940 $\left.\mu \mathrm{gP} . \mathrm{pl}^{-1}\right) \mathrm{P}$ levels without differing from the clones P 150 (7604 $\left.\mu \mathrm{gP} . \mathrm{pl}^{-1}\right)$ and SMIC 148-A (4890 $\left.\mu \mathrm{gP} . \mathrm{pl}^{-1}\right)$ (Table 1). In the leaves, a reduction in the accumulation of $\mathrm{P}$ by all the clones was also verified under a lower supply of this nutrient in the off-soil cultivation (Table 1). Confirming once again that the greater accumulation of $P$ in tissues is usually due to the greater supply of P (VENEKLAAS et al., 2012). At the low P level, the accumulation of $P$ in the leaves was not different among the potato clones, similar to what occurred for the clones in the in vitro culture, not allowing the classification of the same, which indicates that the accumulation of $\mathrm{P}$ in the leaves alone may not be effective in discriminating genotype variation among potato plants. However, at the high level of $\mathrm{P}$ the clone SMIJ 319-1 presented a P accumulation superior to the others. This clone also showed accumulation of $\mathrm{P}$ in the roots superior to the other clones under low level of $\mathrm{P}$ and also, being greater than that accumulated in the high level of P. This allows us to infer that the clone SMIJ 319-1 was efficient in the acquisition of $\mathrm{P}$, since it accumulates higher amounts of the element when cultivated at a low nutrient level, which allows its cultivation with the use of less phosphate fertilizer without damaging crop productivity (HEUER et al., 2017; ROSE; WISSUWA, 2012;). 
Table 1. Effect of $P$ levels in substrate on $P$ accumulation and the efficiency of $P$ uptake in roots and shoots of potato clones growed in vitro, evaluated at 40 DAI and on roots and leaves of potato clones cultivated off the soil, evaluated at 62 DAP. Santa Maria, RS, 2018.

\begin{tabular}{|c|c|c|c|c|c|c|c|c|c|c|}
\hline \multirow{3}{*}{$\begin{array}{l}\text { Growing system } \\
\text { P level }\end{array}$} & \multicolumn{5}{|c|}{ In vitro } & \multicolumn{5}{|c|}{ Off-soil } \\
\hline & Low & High & & Low & High & Low & High & Low & High & \\
\hline & \multicolumn{3}{|c|}{ Root } & \multicolumn{2}{|c|}{ Shoot } & \multicolumn{2}{|c|}{ Root } & \multicolumn{3}{|c|}{ Leaf } \\
\hline Clone & \multicolumn{9}{|c|}{$\mathrm{P}$ accumulation $\left(\mu \mathrm{gP} \mathrm{pl}^{-1}\right)$} & \\
\hline SMIC 148-A & 3.6 & 7.5 & a & $7.5^{\mathrm{B}}$ & $31.4_{a}^{\mathrm{A}}$ & $644.2^{\mathrm{B}}$ & $4890.4^{\mathrm{A}}$ & $6716.6^{\mathrm{B}}$ & $90574.5^{A}$ & \\
\hline Dakota Rose & 2.5 & 8.8 & a & $3.5^{\mathrm{B}}{ }_{\mathrm{a}}^{\mathrm{a}}$ & $13.3^{\mathrm{A}}{ }_{\mathrm{d}}$ & $810.4_{\mathrm{c}}^{\mathrm{B}}$ & $4168^{\mathrm{A}}{ }_{\mathrm{b}}$ & $18505.2^{\mathrm{B}}{ }_{\mathrm{a}}$ & $51976.6^{A}{ }_{c}$ & \\
\hline SMINIA 793101-3 & 0.9 & 6.1 & $\mathrm{~b}$ & $6.5^{\mathrm{B}} \mathrm{a}$ & $28.1^{\mathrm{A}} \mathrm{b}$ & $674.7^{\mathrm{B}}$ & $3177.2^{\mathrm{A}}{ }_{\mathrm{b}}$ & $7211.7_{\mathrm{a}}^{\mathrm{B}}$ & $29428.2^{A}{ }_{d}$ & \\
\hline SMIB 106-7 & 2.4 & 6.8 & a & $5.7^{\mathrm{B}}{ }_{\mathrm{a}}$ & $17.7^{\mathrm{A}} \mathrm{c}$ & $320.3^{\mathrm{A}}$ & $2307.4^{\mathrm{A}}{ }_{\mathrm{b}}$ & $4201.6^{\mathrm{B}}$ & $47689.1{ }_{\mathrm{c}}^{\mathrm{A}}$ & \\
\hline SMIF 212-3 & 1.7 & 8.0 & a & $8.7^{\mathrm{B}} \mathrm{a}$ & $27.6^{\mathrm{A}}$ & $454.1_{\mathrm{c}}^{\mathrm{A}}$ & $817.6_{b}^{A}$ & $3131_{\mathrm{a}}^{\mathrm{B}}$ & $23073.9^{A}{ }_{d}$ & \\
\hline SMIJ 319-1 & 1.7 & 6.4 & a & $7.2^{\mathrm{B}}{ }_{\mathrm{a}}$ & $22.7^{\mathrm{A}} \mathrm{b}$ & $8229.2^{\mathrm{A}}$ & $6939.7_{\mathrm{a}}^{\mathrm{A}}$ & $11361.1_{\mathrm{a}}^{\mathrm{B}}$ & $116240_{a}^{A}$ & \\
\hline P 150 & 1.1 & 4.6 & $\mathrm{~b}$ & $7.2^{\mathrm{B}} \mathrm{a}$ & $20.8^{\mathrm{A}}$ & $3411.0^{\mathrm{B}}{ }_{\mathrm{b}}$ & $7603.8_{\mathrm{a}}^{\mathrm{A}}$ & $5018.2^{\mathrm{B}}{ }_{\mathrm{a}}$ & $78868.8^{\mathrm{A}}{ }_{\mathrm{b}}$ & \\
\hline Average & $2.0^{\mathrm{B}}$ & $6.9^{\mathrm{A}}$ & & 6.6 & 23.1 & 2077.7 & 4272.0 & 8020.8 & 62550.1 & \\
\hline \multirow[t]{2}{*}{$\mathrm{CV}(\%)$} & \multicolumn{3}{|c|}{23.1} & \multicolumn{2}{|c|}{15.2} & \multicolumn{2}{|c|}{66.6} & \multicolumn{3}{|c|}{36.2} \\
\hline & \multicolumn{10}{|c|}{$\mathrm{P}$ use efficiency $\left(\mathrm{g}^{2} \mathrm{mg}^{-1}\right)$} \\
\hline SMIC 148-A & 0.7 & 0.7 & $\mathrm{a}$ & $1.8^{\mathrm{A}} \mathrm{a}$ & $1.7^{\mathrm{A}} \mathrm{a}$ & $1.2_{\mathrm{a}}^{\mathrm{A}}$ & $0.8_{b}^{\mathrm{A}}$ & 8.2 & 6.3 & $\mathrm{~b}$ \\
\hline Dakota Rose & 0.4 & 0.6 & $\mathrm{a}$ & $0.2_{\mathrm{c}}^{\mathrm{A}}$ & $0.7^{\mathrm{A}} \mathrm{c}$ & $1.9^{\mathrm{A}} \mathrm{a}$ & $0.5^{\mathrm{B}}{ }_{\mathrm{b}}$ & 7.6 & 3.9 & $\mathrm{c}$ \\
\hline SMINIA 793101-3 & 0.5 & 0.5 & $\mathrm{a}$ & $1.4^{\mathrm{A}}{ }_{\mathrm{b}}$ & $1.3^{\mathrm{A}} \mathrm{b}$ & $1.8_{\mathrm{a}}^{\mathrm{A}}$ & $0.5^{\mathrm{B}}{ }_{\mathrm{b}}$ & 3.4 & 3.0 & d \\
\hline SMIB 106-7 & 0.6 & 0.5 & $\mathrm{a}$ & $1.4^{\mathrm{A}}$ & $0.6^{\mathrm{B}} \mathrm{c}$ & $0.7^{\mathrm{A}}{ }_{\mathrm{b}}$ & $0.7^{\mathrm{A}}{ }_{\mathrm{b}}$ & 5.6 & 6.2 & $\mathrm{c}$ \\
\hline SMIF 212-3 & 0.1 & 0.3 & $\mathrm{~b}$ & $0.7^{\mathrm{A}} \mathrm{c}$ & $1.1^{\mathrm{A}} \mathrm{c}$ & $1.7_{\mathrm{a}}^{\mathrm{A}}$ & $2.1^{\mathrm{A}} \mathrm{a}$ & 3.5 & 2.3 & d \\
\hline SMIJ 319-1 & 0.6 & 0.4 & a & $1.5_{\mathrm{b}}^{\mathrm{A}}$ & $1.2_{\mathrm{b}}^{\mathrm{A}}$ & $1.6^{\mathrm{A}} \mathrm{a}$ & $1.6_{\mathrm{a}}^{\mathrm{A}}$ & 17.5 & 15.0 & a \\
\hline P 150 & 0.2 & 0.3 & $\mathrm{~b}$ & $1.5^{\mathrm{A}} \mathrm{b}$ & $0.8^{\mathrm{B}}{ }_{\mathrm{c}}$ & $0.2^{\mathrm{A}} \mathrm{b}$ & $1.0^{\mathrm{A}} \mathrm{b}$ & 10.6 & 6.3 & $\mathrm{~b}$ \\
\hline Average & $0.4^{\mathrm{A}}$ & $0.4^{\mathrm{A}}$ & & 1.3 & 1.1 & 1.3 & 1.0 & $8.07^{\mathrm{A}}$ & $6.14^{\mathrm{B}}$ & \\
\hline CV $(\%)$ & 57.6 & & & & & 68 & & & 38.7 & \\
\hline
\end{tabular}

${ }^{a}$ Averages followed by the same lowercase letter in the columns and the same capital letter in the lines do not differ by Scott-Knott at $5 \%$.

The accumulation of $\mathrm{P}$ generally reflects the supply of $\mathrm{P}$. the EIP is inverse to accumulation (BALEMI. 2011). but in in vitro cultivation the $P$ levels tested did not provide a difference in the EIP. The SMIF 212-3 and P 150 clones showed the lowest root dry mass production per unit of $\mathrm{P}(0.23$ $\mathrm{g}^{2} \mathrm{mg}^{-1}$ ) (Table 1). In the shoot. there was a difference between the P levels only for the SMIB 106-7 and P 150 clones. which showed respectively 127 and $82 \%$ more EIP when grown in medium with low P level. evidenced that. in general. as the supply of $\mathrm{P}$ in the medium and the accumulation of $\mathrm{P}$ in the plant both increase. it is expected that the EIP will decrease for biomass production (MACHADO et al.. 2001). Among the clones. SMIC 148-A showed the highest shoot EIP in both the low $\left(1.8 \mathrm{~g}^{2} \mathrm{mg}^{-1}\right)$ and high $\left(1.7 \mathrm{~g}^{2} \mathrm{mg}^{-1}\right) \mathrm{P}$ levels. while the Dakota Rose and SMIF 212-3 clones presented the smallest EIP in shoot production at both P levels. without differing from SMIB 106-7 and $\mathrm{P} 150$ at the high nutrient level.

In the case of off-soil cultivation. the Dakota Rose and SMINIA 793101-3 clones presented a 300 and $275 \%$ increase in EIP in the roots when grown at low P levels. commercial use of these clones could significantly reduce the consumption of phosphate fertilizers and improve crop production (HEUER et al.. 2017; ROSE; WISSUWA. 2012;). At low P levels the SMIB 106$7\left(0.66 \mathrm{~g}^{2} \mathrm{mg}^{-1}\right)$ and P $150\left(0.25 \mathrm{~g}^{2} \mathrm{mg}^{-1}\right)$ clones are the least efficient in the use of $\mathrm{P}$ in the roots. while at the high P level the SMIF 212-3 and SMIJ 319-1 clones are the most EIPs converting $1 \mathrm{mg}$ of $\mathrm{P}$ into 2.1 and $1.6 \mathrm{~g}$ of root dry mass. respectively. In the leaves. the EIP was $31 \%$ higher at the low P level and the SMIJ 319-1 clone had the highest EIP in the leaves $\left(15 \mathrm{~g}^{2} \mathrm{mg}^{-1}\right)$ and the SMIF 212-3 and SMINIA 793101-3 clones presented the lowest EIP. respectively 2.3 and $3 \mathrm{~g}^{2} \mathrm{mg}^{-1}$. This higher or lower EIP in the leaves observed among the clones of this study can be attributed to the intensity with which the clones redistribute the $\mathrm{P}$ from the older tissues to the younger ones in development (HORST et al.. 1993).

The shoot dry mass production in the in vitro culture under low $\mathrm{P}$ levels were higher for the SMIC 148-A. P 150 and SMIJ 319-1 clones. respectively of $3.7 ; 3.3$ and $3.3 \mathrm{~g} \mathrm{pl}^{-1}$ compared to Dakota Rose and SMIF 212-3 clones. which produced 1.8 and $2.5 \mathrm{~g} \mathrm{pl}^{-1}$. so SMIC 148-A. P 150 
and SMIJ-319 -1 clones were considered efficient in the use of $\mathrm{P}$ for shoot dry mass production in vitro culture (Figure 1A). The clones SMINIA 793101-3 and SMIB 106-7 presented shoot dry mass yields close to the average. which makes it difficult to classify their efficiencies. On the other hand. clones SMIC 148-A. SMINIA 793101-3 and SMIF 212-3 presented the largest increases in shoot dry matter production in response to the increase in P level and are. therefore. considered to be responsive to the increase in $\mathrm{P}$ in production of shoot dry matter. differently from SMIB 106-7. P 150 and Dakota Rose clones that did not respond to the greater availability of $\mathrm{P}$ in the culture medium. Clone SMIJ 319-1 presented mean response to shoot dry mass production (Figure 1A).

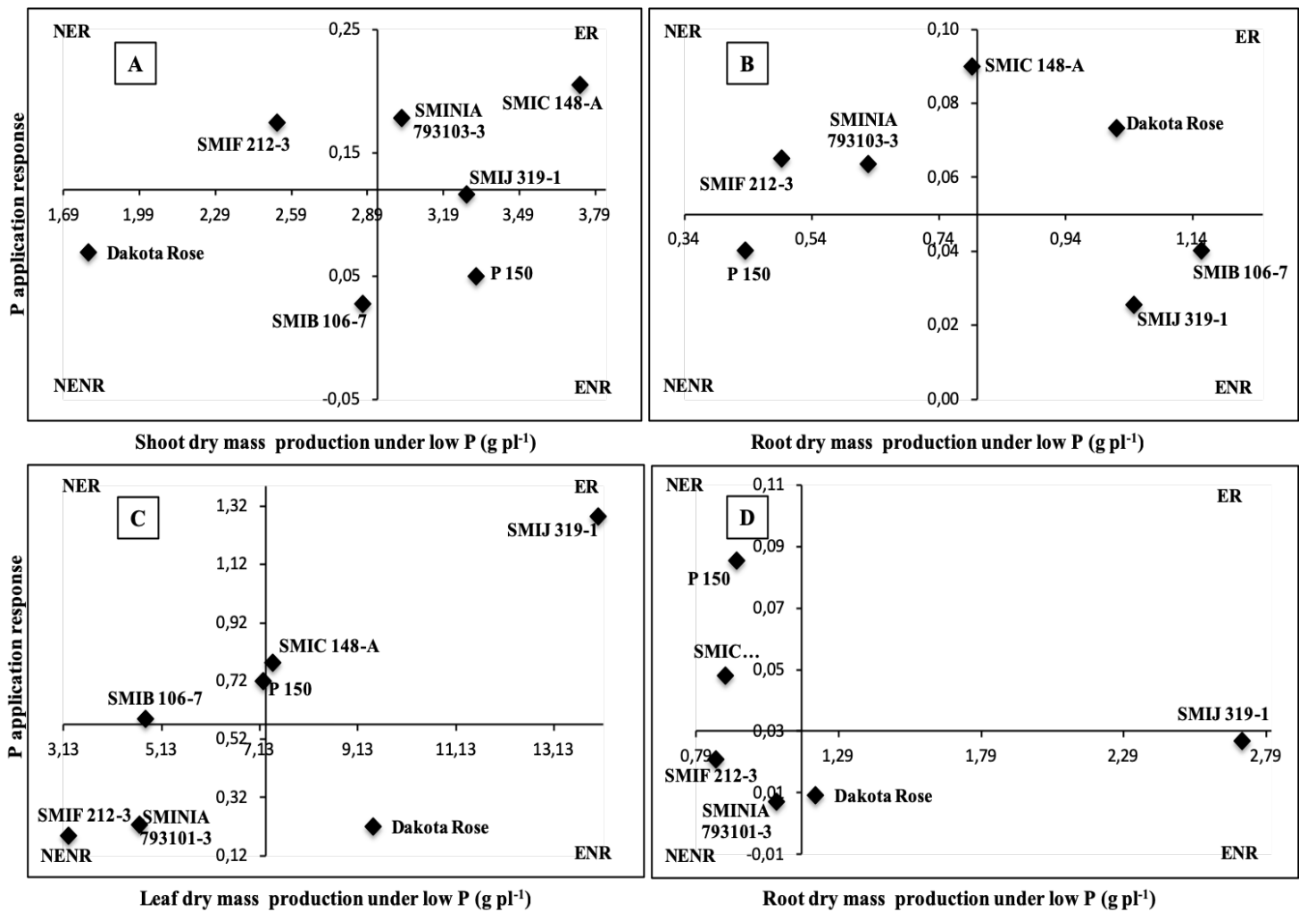

Figure 1. Classification of potato clones regarding the efficiency of use and response to $P$ based on shoot (A) and root (B) dry mass in in vitro culture; and the dry mass of leaves (C) and roots (D) in off-soil cultivation. In the horizontal axis dry mass and in the vertical axis the response of the application of P. Efficient and responsive (ER); non-efficient and responsive (NER); efficient and non-responsive (ENR); and non-efficient and non-responsive (NENR). Santa Maria. RS. 2018

Also in the in vitro cultivation. as for root dry mass production under low P levels. the SMIB 106-7. SMIJ 319-1 and Dakota Rose clones showed the highest yields. respectively of $1.15 ; 1.05$ and $1.02 \mathrm{~g} \mathrm{pl}^{-1}$ compared to the other clones (Figure 1B) and therefore considered as efficient in the use of $\mathrm{P}$ for the production of root dry mass. However. only the clones Dakota Rose. SMIC 148-A. SMINIA 793101-3 and SMIF 212-3 were considered to be responsive to the application of $\mathrm{P}$. since when making more $\mathrm{P}$ available in the culture medium. these were the clones that presented the most increase in root dry mass (Figure 1B).

In the off-soil cultivation. leaf dry mass production under low $\mathrm{P}$ was higher for SMIJ 319-1 and Dakota Rose clones producing 14 and $9.4 \mathrm{~g} \mathrm{pl}^{-1}$. respectively. compared to clones SMIF 212-3.
SMINIA 793101-3 and SMIB 106-7 which respectively produced $3.2 ; 4.7$ and $4.8 \mathrm{~g} \mathrm{pl}^{-1}$. so the clones SMIJ 319-1 and Dakota Rose in off-soil cultivation were considered efficient in the use of $P$ for leaf production (Figure 1C). Regarding the application of P. SMIJ 319-1. SMIC 148-A and P 150 clones were the ones that responded the most with dry leaf mass increment per unit of P. unlike SMIF 212-3. SMINIA 793101-3 and Dakota Rose clones. which were the least responsive (Figure 1C).

As for the root dry mass production under low P levels in off-soil cultivation. SMIJ 319-1 was the clone that produced more root dry mass. $2.7 \mathrm{~g} \mathrm{pl}^{-}$ 1 differing from the others. being in this growing system the only clone considered efficient in the use of $\mathrm{P}$ to produce root dry mass (Figure 1D). Concerning the application of P. only clones P 150 
and SMIC 148-A were considered to be responsive to $\mathrm{P}$ in the production of root dry mass. producing more biomass with the increase of $\mathrm{P}$ in the culture medium (Figure 1D).

The use of high or low nutritional input in agricultural production requires a different approach in the selection of potato clones for the use of $\mathrm{P}$ (HEUER et al.. 2017; WANG et al.. 2010). In a condition of low $\mathrm{P}$ supply. the potato clones with greater efficiency of $\mathrm{P}$ acquisition (due to a greater development of kinetic factors of absorption and/or morphological) and of internal use of $\mathrm{P}$ (translocation and conversion in biomass) (FOX. 1978; MOURA et al.. 2001; WANG et al.. 2010). which will be selected as priority. as in the case of SMIJ 319-1 in off-soil cultivation. In a cultivation condition with high nutrient supply. the efficiency of internal use of $\mathrm{P}$ becomes more important. able to provide reduction in the dose fertilizers to be applied without reduction of production (BALEMI; SCHENK. 2009ab; HEUER et al.. 2017; WANG et al.. 2010). as well as the selection of the clone SMIC 148-A in the culture in vitro.

Thus. the choice of the cropping system for selection use and response to $\mathrm{P}$ by potato clones is crucial for the success of crop improvement programs. Both systems have advantages. but the main in choosing of the system is that the potato clones have a similar $\mathrm{P}$ response to that observed in field cultivation. Therefore. new experiments should be performed comparing these systems with commercial cultivation.

\section{CONCLUSIONS}

The selection of potato clones in the seedling phase. using only as a criterion the accumulation of $\mathrm{P}$ under low nutrient level is not adequate. both in off-soil and in vitro cultivation.

Clones selected as being more efficient in the use of $\mathrm{P}$ in in vitro cultivation have not been shown to be necessarily more efficient in off-soil cultivation.

No clone remains in the same classification group regarding the efficiency of use and response to $\mathrm{P}$. based on the production of dry mass. in the two growing systems.

The selection of potato clones in in vitro culture system was not representative of that of the off-soil growing system for the efficiency of use and response to $\mathrm{P}$. based on dry mass production.

\section{ACKNOWLEDGEMENTS}

The authors are grateful to $\mathrm{CNPq}$ for financial support and to Potato Genetic Improvement Program of the UFSM for the granting of genotypes.

RESUMO: A seleção de plantas de batata (Solanum tuberosum L.) que são eficientes no uso de fósforo (P) desempenha um papel importante no aumento da produtividade das culturas. reduzindo o custo de produção devido ao alto preço dos fertilizantes fosfatados. além de reduzir a poluição do meio ambiente devido ao melhor uso dos fertilizantes aplicados. O objetivo deste trabalho foi comparar o método de seleção de clones de batata quanto à eficiência de uso e resposta ao $\mathrm{P}$ entre sistemas in vitro e fora do solo com o uso de areia como substrato. Para o efeito. os clones de batata SMIC 148-A. Dakota Rose. SMINIA 793101-3. SMIB 106-7. SMIF 212-3. SMIJ 319-1 e P 150 foram cultivados a baixos e altos níveis de P nos sistemas de cultivo in vitro (1.935 e $\left.19.346 \mathrm{mg} \mathrm{P} \mathrm{L}^{-1}\right)$ e fora do solo (2.32 e $\left.23.2 \mathrm{mg} \mathrm{P} \mathrm{L}^{-1}\right)$. A seleção de clones de batata utilizando apenas como critério o acúmulo de $\mathrm{P}$ em baixo nível de nutrientes não é adequada. tanto no cultivo fora do solo quanto no in vitro. Clones selecionados como mais eficientes no uso de $\mathrm{P}$ em cultivo in vitro não se mostraram necessariamente mais eficientes no cultivo fora do solo. Nenhum clone permanece no mesmo grupo de classificação quanto à eficiência de uso e resposta ao P. baseado na produção de massa seca nos dois sistemas de cultivo.

PALAVRAS-CHAVE: Cultura in vitro. Cultivo fora do solo. Nutrição Mineral. Seleção de clones. Solanum tuberosum L.

\section{REFERENCES}

BALEMI. T. Screening for genotypic variation in potato for phosphorus efficiency. International Research Journal of Plant Science, v. 2. p. 233-243. 2011. 
BALEMI. T.; SCHENK. M. K. Genotypic variation of potato for phosphorus efficiency and quantification of phosphorus uptake with respect to root characteristics. Journal of Plant Nutrition and Soil Science, v. 172. $\mathrm{n}$. 5. p. 669-677. 2009. https://doi.org/10.1002/jpln.200800246

BALEMI. T.; SCHENK. M. K. Genotypic difference of potato in carbon budgeting as a mechanism of phosphorus utilization efficiency. Plant and soil, v. 322. n. 1-2. p. 91-99. 2009. https://doi.org/10.1007/s11104009-9897-0

BANDINELLI. M. G.; BISOGNIN. D. A.; GNOCATO. F. S.; MAMBRIN. R. B.; SAUSEN. D.; NICOLOSO. F. T. Concentração dos sais e da sacarose do meio MS na multiplicação in vitro e na aclimatização de batata. Horticultura Brasileira, v. 31. p. 242-247. 2013. http://dx.doi.org/10.1590/S0102-05362013000200011

BISOGNIN. D. A.; BANDINELLI. M. G.; KIELSE. P.; FISCHER. H. Rooting potential of mini-cuttings for the production of potato plantlets. American Journal of Plant Sciences, v. 6. p. 366-371. 2015. http://doi: 10.4236/ajps.2015.62042

FARIAS. J. G.. BERNARDY. K.; SCHWALBERT. R.; DEL FRARI. B. K.; MEHARG. A.; CAREY. M.; MARQUES. A. C. R.; SIGNES-PASTOR. A.; SAUSEN. D.; SCHORR. M. R. W.; TAVARES. M. S.; NICOLOSO . F. T. et al. Effect of phosphorus on arsenic uptake and metabolism in rice cultivars differing in phosphorus use efficiency and response. Anais da Academia Brasileira de Ciências, v. 89. n. 1. p. 163-174. 2017. http://dx.doi.org/10.1590/0001-3765201720160320

FERNANDES. A. M.; SORATTO. R. P.; EVANGELISTA R. M.; JOB A. L. G. Influência do fósforo na qualidade e produtividade de tubérculos de cultivares de batata de duplo propósito. Horticultura Brasileira, v. 34. n. 3. 2016. http://dx.doi.org/10.1590/S0102-05362016003007

FERNANDES. A. M.; SORATTO. R. P. Nutrição mineral. calagem e adubação da batateira. Botucatu: FEPAF; 2012.

FERREIRA. D. F. Sisvar: a computer statistical analysis system. Ciência e Agrotecnologia, v. 35. p. 10391042. 2011. http://dx.doi.org/10.1590/S1413-70542011000600001

FOX. R. H. Selection for phosphorus efficiency in corn. Communications in Soil Science and Plant Analysis, v. 9. p. 13-37. 1978. https://doi.org/10.1080/00103627809366784

GODFRAY. H. C. J.; BEDDINGTON. J. R.; CRUTE. I. R.; HADDAD. L.; LAWRENCE. D.; MUIR. J. F.; PRETTY. J.; ROBINSON. S.; THOMAS. S. M.; TOULMIN. C. Food Security: The Challenge of Feeding 9 Billion People. Science, v. 327. n. 5967 p. 812-818. 2010. http://doi: 10.1126/science.1185383

HAMMOND J. P.; BROADLEY M. R.; WHITE. P. J.; KING. G. J.; BOWEN. H. C.; HAYDEN. R.; MEACHAM. M. C.; MEAD. A.; OVERS. T.; SPRACKLEN. W. P.; GREENWOOD. D. J. Shoot yield drives phosphorus use efficiency in Brassica oleraceae and correlates with root architecture traits. Journal of Experimental Botany, v. 60. n. 7. p. 1953-1968. 2009. https://doi.org/10.1093/jxb/erp083

HEUER. S.; GAXIOLA. R.; SCHILLING. R.; HERRERA-ESTRELLA. L.; LÓPEZ-ARREDONDO. D.; WISSUWA. M.; DELHAIZE. E.; ROUACHED. H. Improving phosphorus use efficiency: A complex trait with emerging opportunities. The Plant Journal, v. 90. n. 5. p. 868-885. 2017. https://doi.org/10.1111/tpj.13423

HORST. W. J.; ABDOU. M.; WIESLER. F. Genotypic differences in phosphorus efficiency of wheat. In: BARROW. N. J. (Ed.). Plant nutrition - from genetic engineering to field practice. Dordrecht: Kluwer Academic Publishers. p. 367-370. 1993.

LUCA. E. F.; BOARETTO. A. E.; MURAOKA. T.; CHITOLINA. J. C. Eficiência de absorção de fósforo (32P) por mudas de eucalipto e arroz. Scientia Agricola, v. 59. p.543-547. 2002.

https://doi.org/10.1590/S0103-90162002000300020 
LYNCH. J. P. Root architecture and plant productivity. Plant Physiology, v. 109. p. 7-13. 1995.

MILLAM. S.; SHARMA. S. K. 2008. Soil-Free Techniques. In: VREUGDENHIL D; BRADSHAW. J.; GEBHARDT. C.; GOVERS. F.; MACKERRON. D. K. L.; TAYLOR. M. A.; ROSS. H. A. (eds). Potato biology and biotechnology. advances and perspectives. Amsterdam. p. 705-716.

MOURA. W. M.; LIMA. P. C.; CASALI. V. W. D.; PEREIRA. P. R. G.; CRUZ. C. D. Eficiência nutricional para fósforo em linhagens de pimentão. Horticultura Brasileira, v. 19. p. 174-180. 2001.

http://dx.doi.org/10.1590/S0102-05362001000300002

MURASHIGE. T.; SKOOG. F. A revised medium for rapid growth and bioassays with tobacco tissue culture.

Physiologia Plantarum, v. 15. p. 473-497. 1962.

PLAXTON. W. C. Plant Response to Stress: Biochemical Adaptations to Phosphate Deficiency. Encyclopedia of Plant and Crop Science, p. 976-980. 2004. https://doi.org/10.1081/E-EPCS 120010648

ROSEN. C. J.; BIERMAN. P. M. Potato yield and tuber set as affected by phosphorus fertilization. American Journal of Potato Research, v. 85. p. 110-120. 2008. https://doi.org/10.1007/s12230-008-9001-y

ROSE. T. J.; WISSUWA. M. Rethinking internal phosphorus utiliza- tion efficiency (PUE): A new approach is needed to improve PUE in grain crops. Advances in agronomy, Academic Press. p. 185-217. 2012. https://doi.org/10.1016/B978-0-12-394277-7.00005-1

SCOTT. A. J.; KNOTT. M. A cluster analysis method for grouping means in the analysis of variance.

Biometrics, v. 30. p. 507-512. 1974.

SHEN. J.; YUAN. L.; ZHANG. J.; LI. H.; BAI. Z.; CHEN. X.; ZHANG. W.; ZHANG. F. Phosphorus Dynamics: From Soil to Plant. Plant Physiology, v. 156. p. 997-1005. 2011.

https://doi.org/10.1104/pp.111.175232

SIDDIQI. M. Y.; GLASS. A. D. M. Utilization index: a modified approach to the estimation and comparison of nutrient utilization efficiency in plants. Journal of Plant Nutrition, v. 4. p. 289-302. 1981.

https://doi.org/10.1080/01904168109362919

SILVA. G. O.; NEY. V. G.; DA SILVA PEREIRA. A.; TERRES. L. R. Relações entre caracteres de tubérculo de batata nas primeiras gerações de seleção. Ceres, v. 61. p. 370-376. 2014.

SILVA. G. O.; PEREIRA. A. da S. Seleção em gerações iniciais para caracteres agronômicos em batata. Horticultura brasileira. v. 29. p. 449-455. 2011. http://dx.doi.org/10.1590/S0102-05362011000400001

SORATTO. R. P.; PILON. C.; FERNANDES. A. M.; MORENO. L. A. Phosphorus Uptake. Use Efficiency. and Response of Potato Cultivars to Phosphorus Levels. Potato Research, 2015.

https://doi.org/10.1007/s11540-015-9290-8

TESTER. M.; LANGRIDGE. P. Breeding Technologies to Increase Crop Production in a Changing World. Science. v. 327. n. 5967. p. 818-822. 2010. https://doi.org/10.1126/science.1183700

VENEKLAAS. E. J.; LAMBERS. H.; BRAGG. J.; FINNEGAN. P. M.; LOVELOCK. C. E.; PLAXTON. W. C.; PRICE. C. A.; SCHEIBLE. W.; SHANE. M.W.; WHITE. P. J.; RAVEN. J. A. Opportunities for improving phosphorus use efficiency in crop plants. New Phytologist, v.195. p. 306-320. 2012.

https://doi.org/10.1111/j.1469-8137.2012.04190.x 
WANG. X.; SHEN. J.; LIAO. H. Acquisition or utilization. which is more critical for enhancing phosphorus efficiency in modern crops. Plant Science. v. 179. n. 4. p. 302-306. 2010.

https://doi.org/10.1016/j.plantsci.2010.06.007

WISSUWA. M.; KONDO. K.; FUKUDA. T.; MORI. A.; ROSE. M. T.; TANAKA. J. P.; KRETZSCHMAR. T.; HAEFELE. S. M.; ROSE. T. J. Unmasking novel loci for internal phosphorus utilization efficiency in rice germplasm through Genome-Wide Association Analysis. PLoS One, v. 10. n. 4. p. 1-21. 2015.

https://doi.org/10.1371/journal.pone.0124215 